\title{
Insurance Sector Development and its Effect on the Financial Markets in Developing Countries: The Case of Kosovo
}

\author{
B. Haliti Baruti
}

\begin{abstract}
The purpose of this paper is to extract the important factors in the nature of insurance companies and their direct role in the economic and financial system development. This market study aims to analyse the insurance system in Kosovo by determining and then analysing its structure, the degree of concentration of insurance companies on the insurance market, their behaviour towards price, number of participants, companies operating in this market and types of products and services they provide. Our analysis are gathered on statistical and qualitative data through the study of the theories on insurance market development in other countries. Furthermore, for the empirical analysis, we used secondary data from Central Bank of Kosovo, Insurance Companies and Association Insurance of Kosovo. Also, we conducted two surveys. First, we conducted a survey with finance managers from all insurance companies and secondary survey was in general, for people who work. This way we tried to get a better understanding of the issue at hand. The identification of these factors would enable insurance companies to design policies that tackle the demands of consumers for voluntary insurance policies and at the same time to contribute to financial stability of Kosovo's economy. At the end we have to come out with conclusions on the main research question: Does Insurance Development affect the Financial Markets in developing countries? The expected outcome is that the insurance sector in Kosovo is an important factor for the further development of the financial system.
\end{abstract}

Index Terms-Insurance Market; Development; Financial System, Economic Growth

*This paper will be part of PhD thesis at the University American College Skopje

\section{INTRODUCTION}

Developing a sustainable insurance system is a prerequisite for developing an economy. The Kosovo Insurance Market has experienced a relatively positive development over the last decade and has been characterized by ongoing reforms, especially with the entry of new companies by offering new services. With a share of 3.0 percent in total financial system assets, the insurance sector is the fourth largest sector by size. Penetration rate of 1.4 percent (gross written premiums in relation to GDP) is estimated to be relatively low, which remained almost unchanged in the last three years mainly as a result of higher GDP growth versus written premiums in the insurance sector. Meanwhile, the density level, which represents the written premiums per capita, is characterized by an increase. The interconnection between the insurance sector and other segments of the financial system is still at a low level, which minimizes the risk distribution options in other segments of the financial system of Kosovo. The highest interconnection of the insurance sector lies with the banking sector since around half of the assets of this sector remain in commercial banks in the form of deposits (Annual Report CBK). The structure of the insurance sector continues to be dominated by 'non-life' insurance services, while the remainder consists of the assets of the 'life' insurance companies. This structure contrasts with the structure of the insurance sector in EU member states. Regarding research in this work, several previous papers are important to mention. The research conducted by reference [6] has come to the conclusion that both forms of insurance are developed: life insurance and nonlife insurance, with the latter dominating the market. The insurance market in Kosovo today is quite consolidated and has sufficient financial and professional capacities to provide various insurance coverage. This coverage offers protection to citizens and their businesses from different events whether they are natural disasters or insurance on health, life, property, responsibilities, various accidents etc. Other academic studies have analysed the insurance effect on economic growth. As per the direct effect of insurance on financial markets development, it requires further academic studies and exploration. However, based on studies in Kosovo and compared with studies of other countries I can say that Kosovo should be noted that, there are still challenges ahead to overcome and achieve even more qualitative services, further enhancement type of insurance policy offers and contemporary products, methods and ways forward of management to achieve European standards. Moreover, reference [1] claims that insurance markets drive economic growth by enabling a more efficient management of risks and domestic savings. Reference [1] (p. 398) adds that "both life and nonlife insurance premiums have a positive and significant effect on economic growth". Further, reference [1] adds that life insurance impacts growth only in high-income countries, while non-life insurance impacts growth in both high-income and developing countries. Reference [5] have analysed two impacts of insurance markets on the countries: the impact of insurance investment and premiums on GDP growth in Europe. Based on these two impacts, they studied the role of insurance markets on financial market growth. Reference [5] conducted their analysis based on panel data of 29 European countries from 1992 to 2005 . The evidence from 15 EU countries suggests that life insurance markets has positive impact on GDP growth, on the other hand the larger impact for liability insurance came from the New EU Member States from Central and Eastern Europe. Reference [3] have examined the insurance industry in Romania by analysing insurance market data gathered for 16 years and comparing them to other international markets. The study focuses on the impact of the insurance businesses, and life insurance and non-life insurances on the economic growth. The results of the analysis showed that in all observed countries, where the economic development is higher also the weight of insurance 
to the GDP of that countries is higher than $10 \%$, in some European countries it is even higher [3]. The insurance companies just like the others institutional investors may not only help to improve the allocation of capital, but also further strengthen their investments through enhanced surveillance [10]. Furthermore, the insurance companies have large cash inflows and reserves, which may be partly invested in less liquid instruments as bonds and equities. In Kosovo since the beginning of the operation of insurance companies, which is over 18 years, the market still dominates high number of uninsured vehicles and low number of other type of insurances, which, to some extent, is a burden on economic entities, and thus the economy as a whole. This thesis focuses on Kosovo as a developing country in transition, its insurance market and its effect on financial system. The effect of insurance market on financial market can be explored by considering the functioning of the insurance system as a whole and its special segments, regulatory and supervisory instruments and the role of the insurance system in savings mobilization and effective competition

\section{LITERATURE REVIEW}

The Insurance market has been examined through many studies and by many authors due to its importance in today's economy. A cross-country study on the influence of insurance markets on economic growth, conducted by [1], tests the relationship between insurance activity and economic growth. Reference [1] (p. 921) states that, "using the generalized method of moments (GMM) for dynamic models of panel data for 55 countries between 1976 and 2004, I find robust evidence for this relationship". Reference [1] claims that insurance markets drive economic growth by enabling a more efficient management of risks and domestic savings. Reference [1] (p. 398) adds that "both life and nonlife insurance premiums have a positive and significant effect on economic growth". Further, [1], adds that life insurance impacts growth only in high-income countries, while non-life insurance impacts growth in both high-income and developing countries. Reference [5] have analysed two impacts of insurance markets on the countries, the impact of insurance investment and premiums on GDP growth in Europe. Based on these two impacts, reference [5] studied the role of insurance markets on finance-growth. Reference [5] conducted their analysis based on panel data of 29 European countries from 1992 to 2005. From 15 EU countries evidence suggests that life insurance markets has positive impact on GDP growth, on the other hand the larger impact for liability insurance came from the New EU Member States from Central and Eastern Europe [5]. Further, reference [5] (p. 405) add that the "risk transfer (i.e. bearing risk for other economic agents which might stabilise their income streams, dampen volatility and enhance economic activity) and investment (e.g. by increasing over-all investment volumes, by deepening capital markets and by broadening the investment range) as major channels through which the insurance sector may aid economic growth". Therefore, reference [5] state that the results of the analysis showed that in all observed countries the insurance markets have a positive influence on economy dipnet though with significantly different intensity. Further, reference [5] add that insurance sector has to be paid more attention in financial sector analysis and macroeconomic policy. Reference [3] have examined the insurance industry in Rumania by analysing insurance market data gathered for 16 years and comparing them to other international markets. The study focuses on the impact of the insurance businesses, and life insurance and non-life insurances in the economic growth. The results of the analysis showed that in all observed countries, where the economic development is higher also the weight of insurance to the GDP of that countries is higher than $10 \%$, in some European countries it is even higher [3]. Further, reference [3] (p. 323) add that "the correlation obtained between the GDP per capita and the insurance share in GDP shows a greater influence of the life insurance market than that of the non-life insurance, a very difficult thing to attain in our country, where non-life insurance predominates". Reference [3] conclude that the Romanian citizen's potential of insurance is shaped by the society, income, education, culture and the way of life; therefore, life insurance sector is yet to be fully developed. The study conducted by reference [8], investigates the relationship between insurance, banking, and economic growth in India during the post-liberalized period. Reference [8] claim that the banking sector development does not positively affect neither of economic growth or insurance development. However, reference [8] find that insurance industry plays a crucial role in driving economic growth and positively influence the banking sector development. As reference [8] (p. 2202) further add "the findings in our study underline the crucial role of insurance, highlighting that insurance is one of the key factors in the financial system that aids in economic growth". Reference [12] study the relationship between insurance industry development and economic growth during the period of 2006-15, including data from 20 countries and using three distinct proxies such as net written premiums, penetration and density. Reference [12] found a positive relationship between insurance and economic growth in both the developed and developing countries. However, according to reference [12], insurance market effect is limited in some developing countries based due to the limited opportunities for the development of private insurers and foreign investors in countries with less economic development. Reference [4] study the relationship between insurance market penetration and the economic growth in Eurozone countries for the period 1980-2014. Reference [4] measure the impact of insurance market penetration based on three indicators: life insurance, non-life insurance, and both line and non-line combined. Reference [4] claim that insurance markets there are cases that insurance markets drive economic growth while in some cases the economic growth is the one that affects insurance markets instead. Therefore, reference [4] conclude that insurance markets and economic growth are connected in a two-way relationship that affect each other. Reference [4] suggest that through policy regulations, countries can attain benefits of economic and insurance market growth.

\section{METHODOLOGY}

The purpose of this study, as mentioned above, is to identify the connection of the insurance market with the financial markets, its impact on the development and stability of the financial system. To study this phenomenon, we will be using quantitative and qualitative research methods. For this 
purpose, the existing literature (in English and Albanian language) will be used and for the empirical analysis we will be using data from national and international sources (Central Bank of Kosovo, Insurance Companies of Kosovo, Kosovo Insurance Bureau, Association Insurance of Kosovo, Council of bureau and International Association of Insurance Supervisors). The data collected from these sources will be subject of analysis by using the usual quantitative statistical methods. The data used in this analysis will be from 2000 , the year when the insurance market began to develop faster in Kosovo, up to the current state of the insurance market in Kosovo. The data will be processed through the SPSS program for analysis purposes. This research will be implemented through questionnaires (qualitative method) in order to collect information.

\section{A. First Survey}

The questions included in the questionnaire are intended for Finance directors of insurance companies in Kosovo who are expected to respond about the financial conditions of the companies, incomes and expenses, product sales and will provide their opinion as an insurance market expert on sector's current state of affairs. By these questions they were asked how they see the chances for positive change and what the actions that need to be taken are. Combined with the literature and statistical data, results of survey will provide an additional perspective for an in-depth analysis of the impact of insurance market on the financial market in Kosovo.

\section{B. Second Survey}

The main focus of the survey was on the question: Why the majority of Kosovo citizens don't buy voluntary insurance? It refers to the results obtained from our survey conducted from employees with a monthly income, which are or can be insurance buyers. The questionnaires that we distributed was approximately to 800 employees, but only 300 of them has answered.

\section{The Development Trends of the Insurance Industry in Kosovo}

After the war was finished in 1999, Kosovo was put under administration by the international community so called UNMIK, with the aim of establishment and consolidation of state mechanisms including here the insurance market as well. Most of the insurance companies have started their work during year 2000, such as I.C "Kosova", I.C "Insig", I.C "Siguria", and I.C "Dardania". To these Insurance Companies was issued a temporary work permit from UNMIK Administration. In the first half of year 2001 respectively, in August, the first steps of building an efficient insurance system in Kosovo were set up with the creation of a supervisory department of insurance companies in Kosovo operating under the Payments Authority of Kosovo (BPK) later transformed into the Central Banking Authority of Kosovo (CBAK) and in 2008 it was appointed as the Central Bank of Kosovo (CBK). During the first half of year 2002, all insurance companies applied for licenses, although some of them had started work during year 2000. After the completion of all legal licensing procedures as required by Regulation 2001/25. Insurance Market has experienced a relatively positive development over the last decade and has been characterized by ongoing reforms, especially with the entry of new companies by offering new services.

The Central Bank of Kosovo (former Private bank of Kosovo), approves the licensing and supervision of insurance companies in the country, based on two laws: 04/L - 018 Law on Compulsory Motor Liability Insurances and 05/L - 045 Law on Insurances.
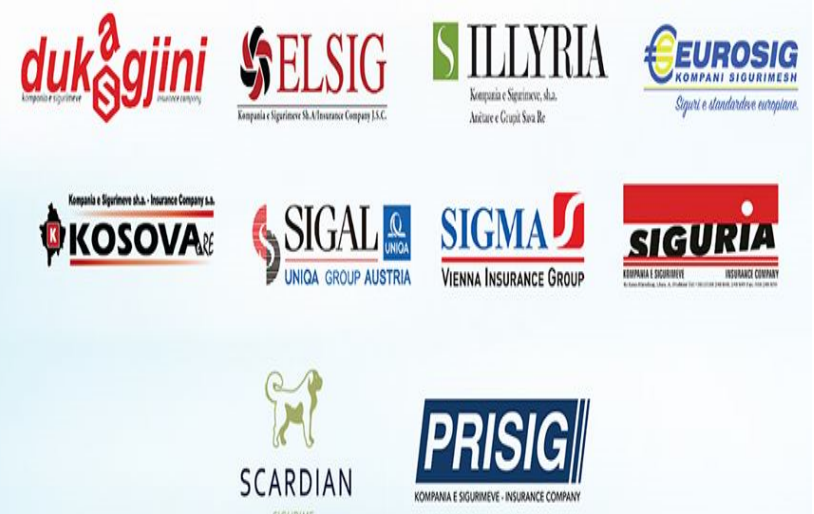

The number of insurance companies remained unchanged, which by December 2018 was 15, out of which 12 were 'nonlife' insurance companies and 3 'life' insurance companies [2]. This year 1 bankrupt, where $62.2 \%$ is foreign capital and total number of employees within the above companies' amount 2,141 people. The supervisory and regulatory institution, the Central Bank of Kosovo, approves the licensing and supervision of insurance companies in the country, based on the existing legal framework.

\section{Performance and Stability of Insurance Market}

Recent developments in the insurance market in Kosovo have not shown positive results and in 2016 they have indicated a negative balance in their performance. As we know the insurance market in developed countries marks a well stability and performance, but at the end of year 2018 insurance companies in Kosovo has change a little bit on positive way. The indicators that are commonly used to show the performance of an insurance company depend heavily on organization and functioning of companies based on law.

In Kosovo, these indicators are used based on which performance is measured: The ratio of damages paid, Report of losses, Margin of profit, Financial power, Expense Report and Minimum Margin of Solvency Financial performance indicators of insurance companies that help us to analyse of the company's performance are:

- Liquidity Indicators,

- Profitability Indicators,

- Security Indicators,

- General Indicators.

Insurance companies have the opportunity to push their activity to increase the mileage of the mileage, as well as to create financial stability. Insurance company should use the stability indicators that we mentation before with which we can imply successful business are. Based on data from Central Bank of Kosovo in this figure, one can note that the insurance market is not at a satisfactory level and has room 
for development. The insurance sector accounts for 3.0 percent of assets in the financial market in Kosovo. Penetration rate of 1.4 percent (gross written premiums in relation to GDP) is estimated to be relatively low. The net profit of Kosovo insurers decreased to EUR 100,000 at the end of March 2019, from EUR 400,000 a year earlier. The assets held by Kosovo insurance companies totalled EUR 181.0 million vs. EUR 175.5 million a year before, of which EUR 164.3 million related to non-life insurers.

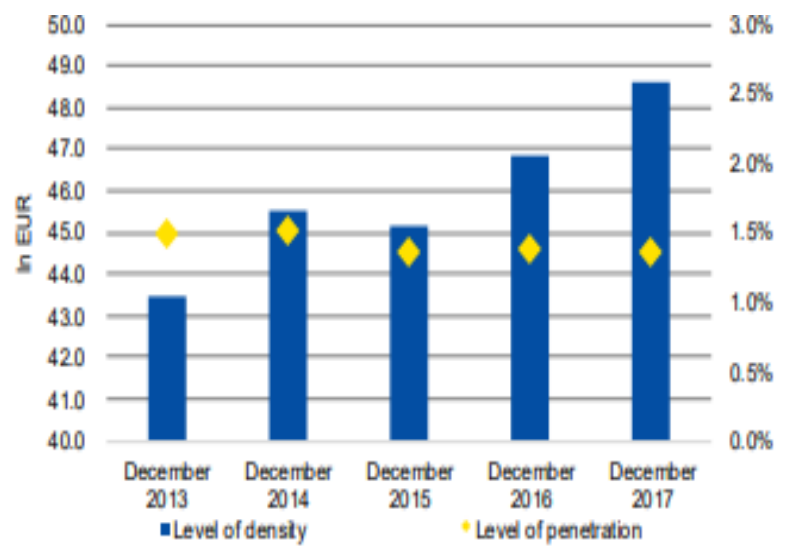

Fig. 1. Insurance sector development indicators (CBK, 2018).

The structure of the insurance sector continues to be dominated by 'non-life' insurance services, which represents 87.8 percent of the insurance market assets, while the remainder consists of the assets of the 'life' insurance companies.

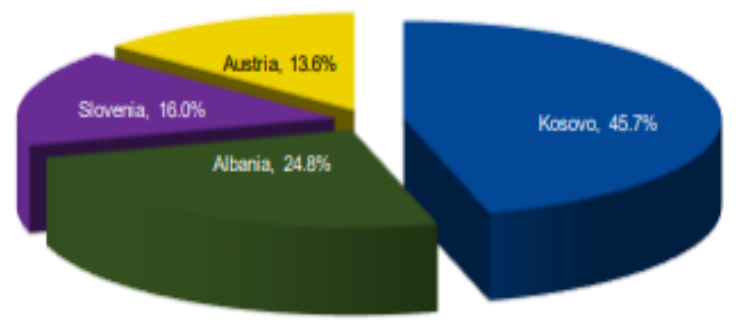

Fig. 2. Assets structure of insurance sector, by ownership (CBK, 2018).

Of total value of premiums written in year 2017-2018 marked an increase by $4.4 \%$ or amounted to EUR 86.7 million, compared to the previous period. About $96.9 \%$ of revenues came from "non-life" insurance sector, which increased by $4.7 \%$, while "life" insurance revenues amounted to $3.1 \%$, and marked a decline from $3.7 \%$ compared to the previous period.

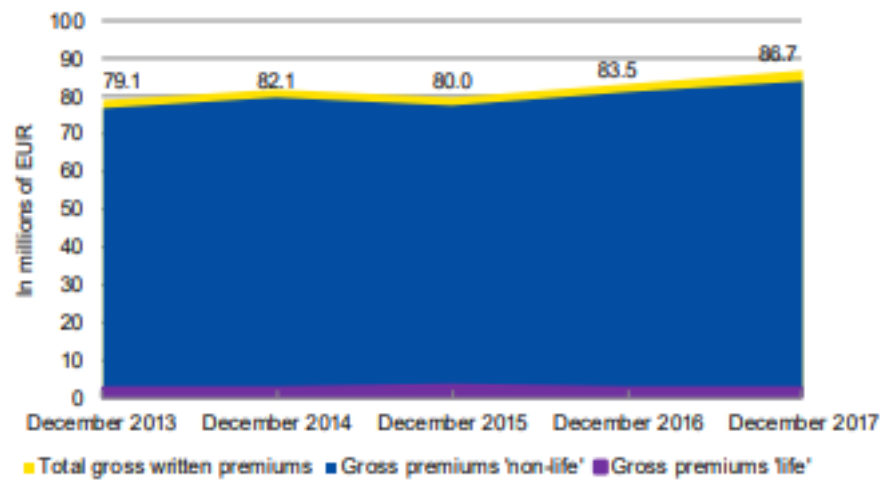

Fig. 3. Received gross premiums (CBK, 2018).

\section{E. Results of First Survey}

A summary of all responses of financier director of insurance company:

- Most of them have been for over 15 years on the market

- All of them are operating all over the country

- Out of 14 companies, 4 response was that they operated with domestic capital, 1 company declared that in the beginning they started with domestic capital and after a while continued with foreign capital and the 8 other companies are operating with foreign capital.

- All of the insurance companies have from 100 to 160 employers.

- The main insurance products for both companies and households are the compulsory motor liability insurance.

- Out of 14 companies, 2 responded that they didn't do any marketing for a long time now, 6 responded that they do marketing from time to time, while the rest of the companies are actively running marketing campaigns.

- The competition in the market for most of them is not loyal.

- The taxes they pay to the state are $18 \%$ VAT and $5 \%$ taxes on gross premiums. For example, on average for the companies the annual with handling taxes and accumulated VAT reaches the amount of 1.5-2.0 million Euro.

- All the financial director of I.C think that the applicable law should be respected and implemented and then this law should be advanced in accordance with EU legislation.

\section{F. Results of Second Survey}

The main focus of the survey was on: Why the majority of Kosovo citizens don't buy voluntary insurance? According to the results obtained from our survey conducted from people who works with a monthly income, who are or can be insurance buyers. Thus, after reviewing the literature, after examining the various theories and methods that were 
analysed for the use of this thesis, we came to different conclusions which are further elaborated based on data collection and analysis.

\section{G. Reliability Analysis}

Reliability analysis helps us to determine if we have sufficient reliability of the questionnaire. In a way this analysis after its extraction allows us to proceed further with the other analyses, in which case the validity of the questionnaire is understood. Based on the results of this analysis, the results of this research indicate that we have good reliability of the questionnaire, worth 820 .

\begin{tabular}{lll}
\multicolumn{3}{c}{ TABLE I: RELIABILITY ANALYSIS } \\
\hline Cronbach's alpha & $\begin{array}{l}\text { Cronbach's alpha } \\
\text { based on } \\
\text { standardized } \\
\text { questions }\end{array}$ \\
\hline, 820 &, 846 & 10 \\
\hline
\end{tabular}

\section{H. Frequency Analysis}

Frequency analysis describes the data, in which case quantitative research presents the data in the frequency range or by percentage $(\%)$ where we understand respondents' responses starting from the lowest to the highest.

$$
\square \text { Yes } \square \text { No }
$$

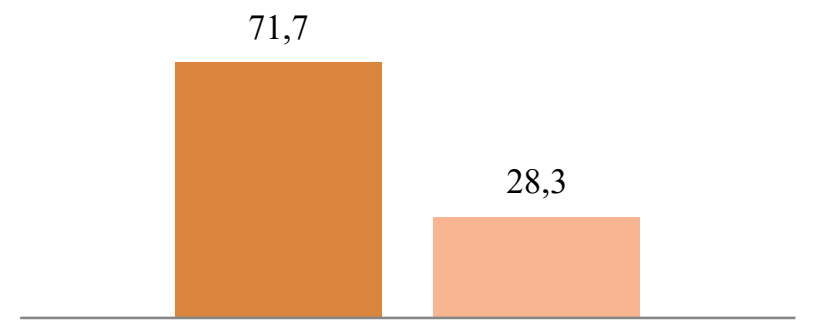

Do you have any of the insurance

Fig. 4. Respondents' answers about whether they buy health insurance.

Based on fig. 4. regarding the question: "Do you have any of the insurance?" we understand that $71.7 \%$ of the respondents answered that they have health insurance, while if we talk about the rest about $28.3 \%$ of the respondent's report that they do not have life insurance.
- Vehicle insurance

- Life insurance

- Health insurance

- Other insurances

Vehicle and Health insurance

$\square$ Life and Vehicle insurance

- Vehicle, life and health insurance

$\square$ Life and health insurance

Vehicle insurance, health insurance and other insurance

No answer

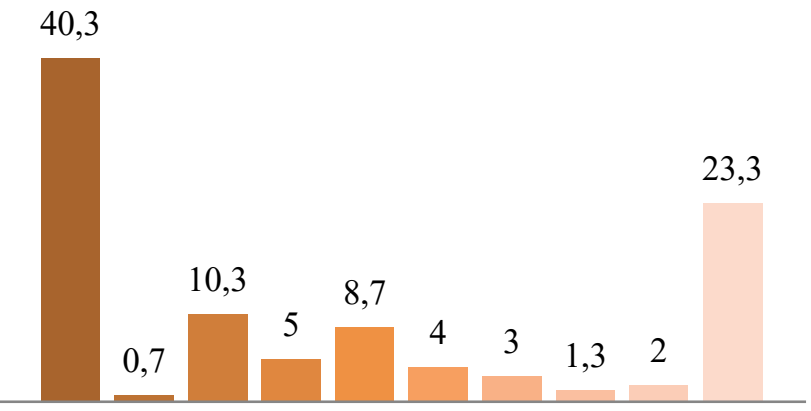

What kind of insurance do you have?

Fig. 5. Respondents' answers about the insurance they have.

Variable: "What kind of insurance do you have?" helps us understand respondents' answers, where about $40.3 \%$ of respondents report having vehicle insurance, a less $0.7 \%$ reporting life insurance, then $10.3 \%$ claiming to have health insurance, around $5 \%$ of respondents reporting other insurances. While now we will tell one or more answer of respondents inside one question so $8.7 \%$ claim to have vehicle and life insurance, then $4 \%$ of respondents emphasize vehicle and life insurance, at the same time $3 \%$ have vehicle, life and health insurance, and $1.3 \%$ have life and health insurance, $2 \%$ report vehicle insurance, health insurance and other insurance, while $1.3 \%$ report that they have all insurance, but it worth to mentation that $23.3 \%$ of respondents do not answer this question at all that we thing they do not have any of type of insurance for many reasons. 
- Not knowing about the importance of insurance

- Unknown application method

Insufficient monthly income

- Other

Not knowledge and income

No answer

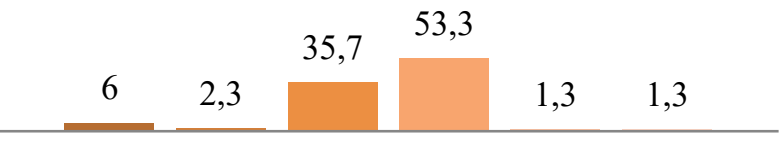

If you do not have insurance choose the reason why?

Fig. 6. Respondents' answers about some reasons why they do not have insurance.

When we talk about question: "If you do not have insurance (life or health), why choose? " it is understood that $6 \%$ of the respondents stated that they do not have insurance due to lack of knowledge about the importance of insurance, then $2.3 \%$ responded to the option related to the unknown way of applying, so they did not have sufficient knowledge properly applies for different insurance, 35.7\% report not having enough monthly incomes so they do not buy any of insurance policy, $53.3 \%$ respond with other option, so we came out with different reasons why they do not buy the insurance, $1.3 \%$ report two options due to insufficient knowledge and low income, while $1.3 \%$ do not answer this question at all.

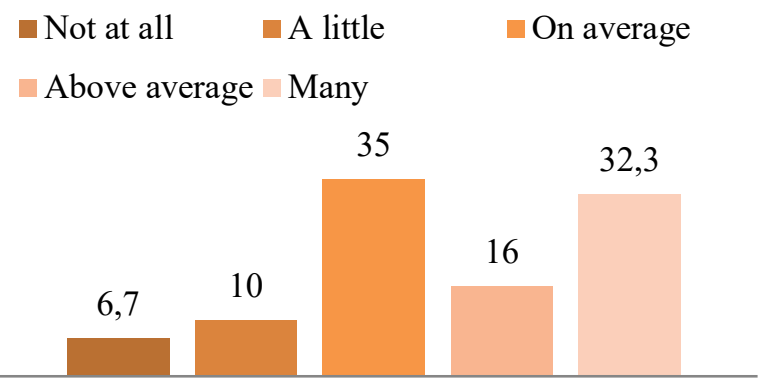

How much does the lack of information about voluntary insurance affect their non-purchase?

Fig. 7. Respondents' answers about the effect that can have a lack of knowledge about the importance of insurance.

Through this variable or question: "How much does the lack of information about voluntary insurance (life insurance, health, etc.) affect their non-purchase?" We understand that $6.7 \%$ of respondents indicate that lack of information about voluntary insurance does not affect their purchase at all, then $10 \%$ report that lack of information can slightly affect nonpurchase of voluntary insurance, while $35 \%$ respond with option on average. Therefore, they believe that lack of information effects on average the non-purchase of voluntary insurance, while $16 \%$ respond to the above average option, thus affecting a moderately high extent, and $32.3 \%$ state that lack of information greatly affects non-purchase of voluntary insurance.

\section{$\square$ Not at all $\quad \square$ little $\quad$ On average \\ Above average $\square$ Many}

23

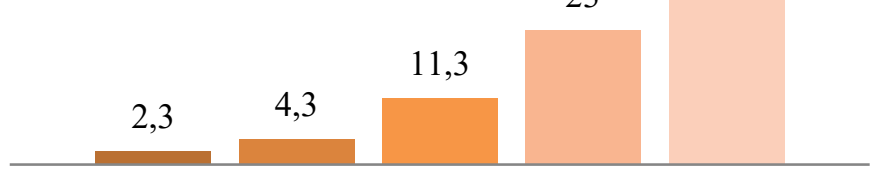

How much does the economic situation in the country affect the non-purchase of voluntary insurance?

Fig. 8. Respondents' answers about the economic situation in the country and its impact affect the non-purchase of voluntary insurance.

Variable of fig. 8 "How much does the economic situation in the country affect the non-purchase of voluntary insurance (other than compulsory motor insurance - motor vehicle insurance)?" It helps us to understand that $2.3 \%$ of respondents report that their economic situation does not affect voluntary insurance at all, while $4.3 \%$ report that their economic situation has little impact on voluntary insurance, then $11.3 \%$ say that the economic situation effects on average not purchasing voluntary insurance, $23 \%$ of them report that the economic situation greatly or above average affects the purchase of voluntary insurance, and the higher figure of $59 \%$ stands for many option, pointing out that the economic situation affects many not purchasing voluntary insurance.

$\square$ Not at all $\quad$ A little $\quad \square$ On average
$\square$ Above average $\square$ Many

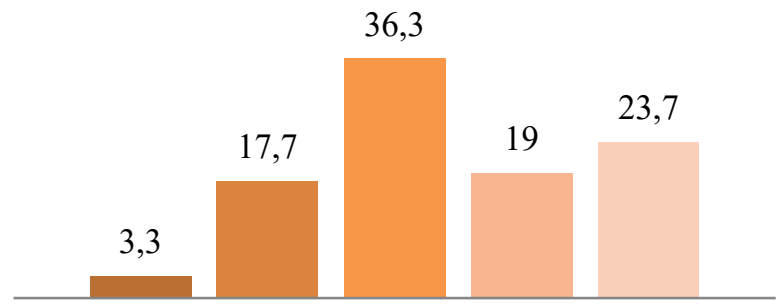

Does the length of the reimbursement (refund) affect the non-purchase of voluntary insurance?

Fig. 9. Respondents' answers about length of the reimbursement from insurance companies for people that they had or have insurances.

Based on question: "Does the length of the reimbursement (refund) affect the non-purchase of voluntary insurance?" we understand that $3.3 \%$ of the respondents report that the length of reimbursement does not affect voluntary insurance at all, then $17.7 \%$ claim that the length of reimbursement may have little effect on not purchasing voluntary insurance, while $36.3 \%$ respond with the option on average, affirming that the length of reimbursement may effect on average the nonpurchase of voluntary insurance, then $19 \%$ report the above average option and $23.7 \%$ emphasize the fact that the length of reimbursement greatly affects the non-purchase of voluntary insurance. 


\section{Correlation Analysis}

Correlational analysis helps us to understand the relationship between the questionnaire variables and the answers given by the respondents. In our case the correlation analysis shows that there is a significant negative relationship between monthly income and the purchase of any type of insurance where $\mathrm{r}=-, 364^{* *}, \mathrm{p}<0.01$. Also, the result of this analysis shows that there is a positive correlation between variables: How much does the economic situation in the country affect the non-purchase of voluntary insurance? And do you have any of the insurance mentioned? Where $\mathrm{r}=, 281^{* *}, \mathrm{p}<0.01$;

TABLE II CORRELATIONAL ANALYSIS ON QUESTIONNAIRE VARIABLES

\begin{tabular}{lllll}
\hline & 1 & 2 & 3 & 4 \\
\hline 1. Monthly income & 1 & & &
\end{tabular}

2. Do you have any of the,$- 364 * * 1$

insurance listed above?

3. How much does the lack $-, 011 \quad, 014 \quad 1$

of information about

voluntary insurance (life

insurance, health, etc.)

affect their non-purchase?

4. How much does the $\quad, 023-, 001,281 * * \quad 1$ economic situation in the country affect the non-

purchase of voluntary

insurance (other than

compulsory motor insurance

- motor vehicle insurance)?

** Significant correlation at the level 0.01 (2- tailed).

* Significant correlation at the level 0.05 (2- tailed).

\section{J. T-Test Analysis}

Even with these results, T-test analysis helps us to understand the differences in the arithmetic mean of the two groups. According to the results of the analysis, the average of 116 participating males is 3.36 and the average of 180 females is 3.46. So, women are affected by different reasons for buying insurance. But there is no significant difference between the groups. Even the Sig (2-tailed) score $(p=, 339 / 316)$ indicates that there is no significant difference between group averages (Sig value is, 026 within $95 \%$ confidence interval).

TABLE II T-TEST ANALYSIS ABOUT GROUP STATISTICS

\begin{tabular}{llcccc}
\hline & Gender & No. & MA & DS & $\begin{array}{l}\text { Errors } \\
\text { in DS }\end{array}$ \\
\hline $\begin{array}{l}\text { Reasons } \\
\text { for buying } \\
\text { insurance }\end{array}$ & Male & 116 & 3,36 &, 936 &, 087 \\
\hline
\end{tabular}

According to the results of the analysis, the average of 118 participating males is 1.16 and the average of 182 females is 1.38. So, females are affected by various reasons for not paying insurance. But there is a very significant difference between the groups. Even the Sig (2-tailed) score $(p=, 000)$ indicates that there is a significant difference between the group averages (Sig value is, 000 within the $95 \%$ confidence interval).

TABLE IV INDEPENDENT SAMPLE TEST

\begin{tabular}{|c|c|c|c|c|c|c|}
\hline \multicolumn{7}{|c|}{ t-test for equality of the mean } \\
\hline \multirow{15}{*}{$\begin{array}{l}\text { Reasons } \\
\text { for } \\
\text { buying } \\
\text { insuranc } \\
\text { e }\end{array}$} & & \multirow{6}{*}{$\begin{array}{l}\text { Sig. } \\
(2- \\
\text { tailed })\end{array}$} & \multicolumn{4}{|c|}{ Chan Mistake $95 \%$} \\
\hline & & & ges & & \multicolumn{2}{|c|}{ Reliability } \\
\hline & & & in & changin & Interval & of \\
\hline & & & MA & & changes & \\
\hline & & & & in DS. & Low & \\
\hline & & & & & High & \\
\hline & $\begin{array}{l}\text { Equality } \\
\text { of }\end{array}$ & ,339 & ,099 &, 103 &,- 105 & ,303 \\
\hline & Assume & ,316 & ,099 & ,099 &,- 095 & 293 \\
\hline & & & & & & \\
\hline & Variance & & & & & \\
\hline & Equality & & & & & \\
\hline & & & & & & \\
\hline & variance & & & & & \\
\hline & not & & & & & \\
\hline & assumed & & & & & \\
\hline
\end{tabular}

TABLE V T-TEST ANALYSIS ABOUT GROUP STATISTICS

\begin{tabular}{|c|c|c|}
\hline & Gender & $\begin{array}{ll}\text { No. MA DS } & \text { Errors } \\
& \text { in DS }\end{array}$ \\
\hline \multirow{2}{*}{$\begin{array}{l}\text { Types of insurances } \\
\text { which they have }\end{array}$} & Male & $1181,16,489,045$ \\
\hline & Female & $1821,38,487,036$ \\
\hline
\end{tabular}

TABLE VI INDEPENDENT SAMPLE TEST

\begin{tabular}{|c|c|c|c|c|c|}
\hline \multicolumn{6}{|c|}{ t-test for equality of the mean } \\
\hline \multirow{13}{*}{$\begin{array}{l}\text { Reason } \\
\text { s for } \\
\text { buying } \\
\text { insuran } \\
\text { ce }\end{array}$} & & \multirow{5}{*}{$\begin{array}{l}\text { Sig. } \\
(2- \\
\text { tailed })\end{array}$} & \multirow{3}{*}{$\begin{array}{l}\text { Change } \\
\text { in MA }\end{array}$} & \multirow{2}{*}{$\begin{array}{l}\text { Mistakes } \\
\text { Of }\end{array}$} & \multirow{5}{*}{$\begin{array}{l}95 \% \\
\text { Reliability } \\
\text { Interval of } \\
\text { changes } \\
\text { Low High }\end{array}$} \\
\hline & & & & & \\
\hline & & & & & \\
\hline & & & & & \\
\hline & & & & in DS. & \\
\hline & Equality & 000 & ,218 & ,058 & ,105,331 \\
\hline & Assumed &, 000 & 218 & 058 & $105 \quad 332$ \\
\hline & Variance & & & & \\
\hline & $\overline{\text { Equality }}$ & & & & \\
\hline & & & & & \\
\hline & variance & & & & \\
\hline & not & & & & \\
\hline & assumed & & & & \\
\hline
\end{tabular}

\section{K. Analysis of Variance (ANOVA)}

Analysis of ANOVA is used to compare differences of means among more than 2 groups, by collection of statistical models and their associated estimation procedures.

Based on Table 6 it is worth noting that the difference between the two variables: "Monthly income" and "Do you have any insurance?" Is presented. Thus, it is understood that we have a correlation between monthly income and insurance paid by individuals, at $\mathrm{p}<.05$ for three values. [F $(2,297)=37,1, \mathrm{p}=, 000]$ 
TABLE VII ANALYSIS OF ANOVA FOR QUESTION ABOUT INCOMES AND THE

\begin{tabular}{llllll}
\hline & $\begin{array}{l}\text { Sum of } \\
\text { Squares }\end{array}$ & df & $\begin{array}{l}\text { Mean } \\
\text { Square }\end{array}$ & F & Sig. \\
\hline $\begin{array}{l}\text { Between } \\
\text { Groups }\end{array}$ & 74,058 & 2 & 37,029 & 37,288 &, 000 \\
\hline $\begin{array}{l}\text { Within } \\
\text { Groups }\end{array}$ & 294,938 & 297 &, 993 & & \\
\hline Total & 368,997 & 299 & & & \\
\hline
\end{tabular}

TABLE VII ANALYSIS OF ANOVA FOR QUESTION ABOUT INCOMES AND THE TYPE OF INSURANCE

\begin{tabular}{llllll}
\hline & $\begin{array}{l}\text { Sum of } \\
\text { Squares }\end{array}$ & df & $\begin{array}{l}\text { Mean } \\
\text { Square }\end{array}$ & F & Sig. \\
\hline $\begin{array}{l}\text { Between } \\
\text { Groups }\end{array}$ & 9,368 & 2 & 4,684 &, 783 &, 458 \\
\hline $\begin{array}{l}\text { Within } \\
\text { Groups }\end{array}$ & 1357,714 & 227 & 5,981 & & \\
\hline Total & 1367,083 & 229 & & & \\
\hline
\end{tabular}

While Table 8 helps us to understand the differences between the other two variables "Age" and "The insurance policies which they have", we come to realize that there is no correlation between age and the insurance they buy for.

Based on the formula $[\mathrm{F}(2,227)=4.7 \mathrm{p}=$, 458] it is understood that the insured respondents do not depend on their age, or exactly these two variables are not correlated with each other.

\section{Regression Analysis}

Regression analysis is intended to test the independent variable with the dependent variable. So, it shows us the impact of the independent variable on the dependent variable.

TABLE IX MODEL SUMMARY

\begin{tabular}{lllll}
\hline Model & $\mathrm{R}$ & $\begin{array}{l}\mathrm{R} \text { in Adaptation } \\
\text { square }\end{array}$ & $\begin{array}{l}\text { Errors in } \\
\text { in R square } \\
\text { evaluation }\end{array}$ \\
\hline 1 &, $364^{\mathrm{a}}$ &, 133 &, 130 &, 465 \\
\hline
\end{tabular}

a. Predictor (Constant), Monthly incomes

b. Dependent variable: purchase of insurance

Based on the findings in Table 9, regression analysis shows that there is no significant relationship between "Monthly Income" and "purchase of insurance". So, the independent variable (Monthly Income), does not affect the dependent variable (purchase of insurance). In this case $\mathrm{R}$ does not represent the correlation, so we have no correlation between variables since $\mathrm{R}=, 364$.

TABLE X SUMMARY OF MODEL

\begin{tabular}{lllll}
\hline Model & $\mathrm{R}$ & $\begin{array}{l}\mathrm{R} \text { in } \\
\text { square }\end{array}$ & $\begin{array}{l}\text { Adaptation in Errors in DS } \\
\text { R square }\end{array}$ & $\begin{array}{l}\text { jurin } \\
\text { evaluation }\end{array}$ \\
\hline 1 &, $063^{\mathrm{a}}$ &, 004 &, 001 &, 828 \\
\hline
\end{tabular}

a. Predictor (Constant): Age

b. Dependent variable: The reason for not buying insurance

Based on the findings of Table 10, according to regression analysis it is understood that there is no significant relationship between "Age" and "Reason for not baying insurance ". Thus, the independent variable (Age) does not affect the dependent variable (Reason for non-payment of insurance). In this case $\mathrm{R}$ does not represent the correlation, so we have no correlation between variables since $\mathrm{R}=, 063^{\mathrm{a}}$.

\section{DISCUSSION AND CONCLUSION}

In the last decade, Insurance Market has experienced a relatively positive growth, characterized with the continuation of reforms, particularly with the entry of new companies into the market by offering new services [1]. The correlation between insurance and economic growth has been analysed by many authors at the international level, as concluded by the literature reviewed insurance market has a positive impact on economic growth. The life insurance impacts growth only in high-income countries, while non-life insurance impacts growth in both high-income and developing countries this opinion is in line with the findings of [1]. Further reference [5] claim that insurance sector must be paid more attention in financial sector analysis and macroeconomic policy, because the relationship between per capita income levels, education, and way of life have an important impact to the population to do also the life insurances not only non-life insurances. Reference [3] the correlation obtained between the GDP per capita and the insurance share in GDP shows a greater influence growth economic, also we can say that many studies used annual real GDP to measure economic growth insurance is measured by annual real insurance premiums, net written premiums and total assets of insurance companies.

This paper focuses on Kosovo as a developing country in transition, its insurance market and its effect on financial system. Based on the literature and given as the evidence that the insurance has a positive relationship with the stock markets development, the developing countries as Kosovo is should undertake of the policies that aim to encourage the insurance development especially life insurance, which will allow to insurance companies to mobilize the significant stable resources for finance the economy through the purchase of financial assets. The effect of insurance market on financial market can be explored continually by considering the functioning of the insurance system as a whole and its special segments, regulatory and supervisory instruments and the role of the insurance system in savings mobilization and effective competition. The insurance products are still considered as luxury goods for people who live in countries with low economic development as we do. We can say the insurance sector needs to pay more attention in financial sector analysis and macroeconomic policy because with a well-organized insurance sector could be one of the vectors catalysts processes of socio-economic development of a country or region, the development of the insurance industry should be treated as a public benefit, as this is its mission. Education with an insurance culture of young people by introducing insure education in high schools and then in universities. 


\section{APPENDIX}

Questions for Financial Directors of Companies

1. For how many years have you been on the market?

2. Is your company with foreign or domestic capital?

3. Do you have offices outside the capital city, in other towns?

4. What is the total number of employees in your company?

5. Which are the main insurance products offered to companies?

6. Which are the main insurance products offered to households?

7. How do you usually approach the clients?

8. Do you have a marketing campaign for your products?

9. How do you see the market competition?

10. What is the approximate annual tax fee you pay to your state?

11. How do you see prospects for market development?

12. What actions should be taken for market development?

\section{Questionnaire for Population}

Let me take this opportunity for expressing my sincere appreciation for your willingness to help me with this research. This is a short survey to study for insurance market in Kosovo. The research findings will be used in the $\mathrm{PhD}$ thesis. Please note that all the information collected will be treated as CONFIDENTIAL.

Title of the thesis: Insurance sector development and its effect on the Financial Markets in developing countries: the case of Kosovo

\section{A. Demographic data}

A1. Date of completion:

A2. Age:

A3. Gender:

A4. Profession:

A5. The sector where you work

1. Public sector (state)

2. Private Sector

3. Public - private

4. Other

A6. Monthly income

1. $[200-400 €]$

2. $[400-600 €]$

3. $[600-800 €]$

4. Over $800 €$

B. The types of insurance for which this research is conducted are:

- Insurance / vehicle insurance

- Life insurance

- Health insurance

- Other insurance
B1. Do you have any of the insurance listed above?

1. Yes

2. No

B2. If yes, what kind of insurance do you have?

1. Auto liability / vehicle insurance

2. Life insurance

3. Health insurance

4. Other insurance

B3. If you do not have insurance (life or health), why choose?

1. Lack of knowledge about the importance of insurance

2. Unknown way of applying

3. Insufficient monthly income

4. Other

\section{Your thoughts about buying / not buying insurance}

$\mathrm{C} 1$. How much does the lack of information about voluntary insurance (life insurance, health, etc.) affect their non-purchase?

1. Not at all

2. A little

3. On average

4. Above average

5. Many

C2. How much does the economic situation in the country affect the non-purchase of voluntary insurance (other than compulsory motor insurance - motor vehicle insurance)?

1. Not at all

2. A little

3. On average

4. Above average

5. Many

C3. Does the duration of the reimbursement (refund) affect the non-purchase of voluntary insurance?

1. Not at all

2. A little

3. On average

4. Above average

5. Many 


\section{REFERENCES}

[1] Arena, M. (2008). Does Insurance Market Activity Promote Economic Growth? A Cross-Country Study for Industrialized and Developing Countries. Journal of Risk \& Insurance, 75(4), pp.921-946.

[2] Center Bank of Kosovo. Monthly Statistics \& Bulletin Monthly Report of Financial System. (2010/2017). Retrieved from https://www.bqk-kos.org

[3] Cristea, M., Marcu, N. and Cârstina, S. (2014). The Relationship between Insurance and Economic Growth in Romania Compared to the Main Results in Europe - A Theoretical and Empirical Analysis. Procedia Economics and Finance, 8, pp.226-235.

[4] Dash, S., Pradhan, R., Maradana, R., Gaurav, K., Zaki, D. and Jayakumar, M. (2015). Insurance market penetration and economic growth in Eurozone countries: Time series evidence on causality. Future Business Journal, 4(1), pp.50-67.

[5] Haiss, P. and Sümegi, K. (2008). The relationship between insurance and economic growth in Europe: a theoretical and empirical analysis. Empirica, 35(4), pp.405-431

[6] Insurance Association of Kosovo. Monthly Bulletin. (2012/2017). Retrieved from https://www.shs-ks.com Images retrieved from: http://rakeback4.me/life-insurance-quotes/life-insurance-quotes-plusinsurance-quotes-wallpaper-backgrounds-91-and-life-insurancequotes-for-seniors-over-70/

[7] Insurance Company, Illyria Life. Annual Reports (2011/2017). Retrieved from https://www.bks-ks.org

[8] Kaushal, S. and Ghosh, A. (2017). Economic growth and the development of banking and insurance sector in the post-liberalized India. International Journal of Social Economics, 44(12), pp.21872207.

[9] Lee, C., Lee, C. and Chiou, Y. (2017). Insurance activities, globalization, and economic growth: New methods, new evidence. Journal of International Financial Markets, Institutions and Money, 51, pp.155-170.

[10] Mohy ul din, S., Regupathi, A. and Abu-Bakar, A. (2017). Insurance effect on economic growth - among economies in various phases of development. Review of International Business and Strategy, 27(4), pp.501-519.

[11] Muhamet. H, and Fidan. Q. (2016) INSURANCE MARKET DISTRIBUTION CHANNELS Kolegji ISPE and AAB reserchergate pp.15-18

[12] Ul Din, S., Abu-Bakar, A. and Regupathi, A. (2017). Does insurance promote economic growth: A comparative study of developed and emerging/developing economies. Cogent Economics \& Finance, 5(1). 